\title{
OS PROCESSOS DE SUBJETIVAÇÃO INFLUENCIADOS PELO CONSUMO DOS PROGRAMAS TELEVISIVOS E SEUS REBATIMENTOS NO ENSINO DE HISTÓRIA NA EDUCAÇÃO BÁSICA
}

André Luis Bertelli Duarte

ESEBA/UFU

andrebduarte@gmail.com

\begin{abstract}
Resumo: O consumo exacerbado dos produtos audiovisuais produzidos para ou exibidos na televisão (séries, telenovelas, filmes, programas de variedades etc.) tem sido cada vez mais frequentemente na vida de crianças e jovens estudantes do ensino fundamental e médio. Seguindo o caminho trilhado por Maria Rita Kehl, pensamos que o consumo das linguagens televisas cria processos de subjetivação que constituem visões de mundo e influenciam significativamente nos modos pelos quais estes estudantes se inserem nos processos de ensino e aprendizagem. Nesta apresentação, iremos problematizar como estes processos de subjetivação contemporâneos se materializam em desafios a serem enfrentados pelos professores e professoras de História da educação básica, sobretudo, nas conflituosas relações que se estabelecem entre uma perspectiva crítica de ensino de História e o consumo espetacular de temas e abordagens do passado oferecido pela televisão.
\end{abstract}

O consumo de produtos audiovisuais - de ficção ou não - tem se acentuado nos últimos anos devido a facilitação do acesso gerada pela popularização do uso de ferramentas com recursos reprodutores de vídeo (celulares, tablets, videogames, Tv's smart) e pela ampliação das plataformas de produção e exibição (notadamente os serviços de streaming). É comum encontrarmos em nosso cotidiano pessoas que aproveitam o "tempo livre" (no ônibus, na sala de espera de hospitais ou nos finais de semana, por exemplo) para assistir a mais um episódio de sua série favorita ou para acompanhar as últimas publicações para vídeo nos canais em que está inscrito.

Esta nova maneira de se relacionar com a tecnologia, e consequentemente com o consumo de produtos audiovisuais, possui desdobramentos vários, desde a gestação de uma nova visão do mundo e das relações sociais até os desafios enfrentados pelas escolas para lidar com esta nova realidade. Neste trabalho, o foco de abordagem recai especificamente sobre o papel que o consumo de programas 
televisivos tem (e pode ter) no ensino de história na educação básica, notadamente a partir de uma reflexão da relação entre história e ficção presente nestes produtos.

$\mathrm{Na}$ experiência diária com a didática da história, pude perceber, com cada vez mais nitidez, como os produtos audiovisuais impactam no aprendizado dos discentes e como, dentre estes, a televisão ocupa um lugar de destaque. Por exemplo, em uma determinada aula sobre o tráfico de pessoas, quase todos os alunos de um determinado ano de ensino trouxeram a novela Salve Jorge (Glória Perez, 2012, Rede Globo) como repertório prévio para o estudo do tema.

A certeza do impacto que estes produtos audiovisuais têm no ensino de história me levou à aprofundar os estudos sobre as possibilidades que estes objetos trazem para o ensino de história. A leitura dos trabalhos do historiador estadunidense Robert Rosenstone concorreu para definir uma provocação que passou a nortear meus esforços: se, como defende Rosenstone, os filmes de ficção e documentários também são capazes de produzir conhecimento histórico, que lugar eles ocupam na didática da história? Como eles podem ser utilizados como mediadores do ensinoaprendizagem em história?

Estas preocupações me levaram a experimentar novas abordagens de temas a muito consagrados nos currículos da disciplina, como a chegada dos portugueses ao Brasil, o bandeirantismo e a independência política do Brasil em relação a Portugal, por exemplo. Nestas experimentações, trabalhei com fragmentos das minisséries $A$ Invenção do Brasil, A Muralha e O Quinto dos Infernos, produtos televisivos que têm como temas, respectivamente, aqueles referidos anteriormente. Os resultados destas experiências foram bastante produtivos: o aumento do interesse dos alunos, a possibilidade de aprofundar as percepções dos gêneros narrativos, as abordagens interdisciplinares que possibilitaram, foram alguns indícios que estas experiências produziram e que motivaram a proposição do atual trabalho.

Antes, entretanto, de entrar nas questões específicas sobre as possibilidades e desafios levantados pelo uso dos produtos audiovisuais no ensino de história, penso ser importante apresentar brevemente as questões políticas e culturais que me motivaram inicialmente a me debruçar sobre esta temática.

Me refiro, especificamente, ao artigo de Maria Rita Kehl intitulado O espetáculo como meio de subjetivação, publicado em 2004, onde a autora reflete acerca dos 
impactos psicológicos, políticos e sociais causados pela espetacularização da sociedade moderna, cujas relações sociais passam a ser "mediadas pelas imagens". Dentre as várias reflexões instigantes que produz, interessa mais de perto o que a autora denomina "processos de subjetivação" mediados pelo consumo espetacular de imagens, e como a televisão representaria, até então, a forma mais acabada deste processo.

Fazendo um interessante jogo entre psicanálise lacaniana, de um lado, e crítica e teoria da cultura (Adorno e Guy Debord), de outro, Maria Rita Kehl expõe que:

Se em qualquer forma de vida humana a primeira certeza de nossa existência se forma a partir da constatação que o Outro nos vê, a visibilidade espetacular que prolonga esta certeza na vida dos adultos hoje é muito diferente do conceito de visibilidade "política" tal como estabelecido por Hannah Arendt. Dependemos do espetáculo para confirmar que existimos e para nos orientar em meio a nossos semelhantes dos quais nos isolamos (KEHL, 2004: p. 49-50).

Em uma sociedade cada vez mais marcada pelo individualismo, pelo isolamento do indivíduo em relação ao coletivo ao qual pertence, característico da cultura neoliberal, o modo como os sujeitos aparentemente se orientam em relação à sociedade é através do consumo espetacular de imagens, sobretudo os produtos audiovisuais televisivos. Daí porque Kehl, a partir de Guy Debord, refere-se às "relações sociais mediadas pelo espetáculo". Podemos observar os fenômenos destes processos de subjetivação mediados pelo espetáculo em diversas ocasiões: em locais marcados pela socialização dos indivíduos - salões de beleza, salas de professores, reuniões familiares, dentre vários outros - os temas discutidos são quase sempre "pautados" pelo noticiário da semana, pelos temas do momento, pelos programas líderes de audiência que, como as relações sociais, se transmutam com um acentuado nível de efemeridade.

A partir das reflexões levantadas por Maria Rita Kehl, passei a questionar e a usar a sala de aula como lugar de pesquisas e experimentações com a seguinte inquietação: neste mundo em radical transformação, como fica a dimensão do conhecimento histórico? Atividade essencialmente escrita, a interpretação e representação do passado seria afetada por estas novas formas de narrar? Neste sentido, podemos afirmar que produtos televisivos que possuam temáticas históricas também podem ser considerados capazes de produzir conhecimento histórico? 
Esta relação entre a História (como atividade profissional, com "H" maiúsculo) e a sua apropriação pelo discurso televisivo foi motivo de preocupação de Eugênio Bucci no artigo "A história na era de sua reprodutibilidade técnica". O texto, cujo título remete ao aclamado ensaio de Walter Benjamin sobre o significado da obra de arte no contexto de sua massificação, parte da constatação, realizada pelo autor, de que:

Vivemos em uma era em que a História entra numa era em que ela é refeita no ritmo do espetáculo - não mais no ritmo da investigação científica. A televisão não cessa, por sua própria natureza, de reciclar o legado histórico, transformando-o. A exemplo do que acontece notícia, com a publicidade, com o entretenimento em geral, a História passou a fazer parte do show cotidiano da TV (BUCCI, 2004: 205206).

Pelas palavras do autor apreendemos que, em sua concepção, a apropriação da História pela televisão produz um deslocamento do significado do conhecimento histórico, que passa a ser produzido não mais a partir do rigor teórico-metodológico característico da disciplina, mas a partir de sua existência como espetáculo, ou seja, a história aparece na televisão não para produzir conhecimento, mas para promover entretenimento.

A crítica de Bucci sobre o lugar da História na televisão se apresenta, neste caso, como uma defesa à legitimidade da História como discurso existente fora da televisão. Para o autor, a força que a televisão demonstra, sobretudo no Brasil, cria uma "ilusão" de que a realidade, presente ou passada, só ganha existência a partir do momento em que ela se transforma em imagem na televisão, evidentemente. É notável nas aulas de história como o interesse e o repertório prévio dos estudantes varia de acordo com o grau de espetacularização dos temas estudados: a Segunda Guerra Mundial, o Nazismo, a Escravidão Negra no Brasil, por exemplo, são temas que despertam maior interesse do que outros correspondentes, fato que, numa análise rasa, refere-se ao grau de espetacularização destes temas - aja vista o número de filmes, séries, documentários, novelas, reportagens especiais publicadas anualmente sobre estes temas na mídia de massas.

A principal preocupação de Eugênio Bucci, neste sentido, refere-se ao fato de que a História apresentada na televisão, transformada essencialmente em entretenimento, pode desbancar a História produzida por historiadores de ofício na concepção geral de conhecimento, interpretação e representação do passado. O 
deslocamento do conhecimento histórico promovido pela televisão significa, para o autor, a perda da capacidade reflexiva da história:

A novidade com a qual somos forçados a trabalhar, a partir do final do século XX, é que a História deixa de ser um discurso que se reescreve a partir do exercício da pesquisa em bases mais ou menos racionais e se converte num discurso passível de reprodutibilidade técnica. [...] trata-se de um modo de produção da memória social que passa longe da mão e da cabeça do historiador. O relato histórico vai se convertendo em passatempo da plateia. É a reprodutibilidade apartada do pensamento.

Agora, a história se reproduz pela mesma máquina de comunicação eletrônica que está socialmente encarregada de registrar os acontecimentos imediatos e de promover o entretenimento; ela se reproduz não segundo os parâmetros da historiografia, mas segundo as leis que ordenam o espetáculo - fundindo fato e ficção -; ela se reproduz segundo o modo de produção das imagens voltadas para o consumo e para o gozo [grifos nossos] (BUCCl, 2004: p. 206.

Aproveitando a inspiração do ensaio benjaminiano, podemos perceber que os argumentos do autor se assentam na constatação de que a historiografia, e seu autor, o historiador, perdem a sua "aura" como produtor de pensamento sobre o mundo e a sociedade a partir do momento em que passam a ser substituídos pela televisão enquanto veículo produtor de memória social que, ao transformar o passado em entretenimento e espetáculo, aliena essa capacidade reflexiva da história, ou seja, converte-a num discurso passível de reprodutibilidade técnica.

Ao tomarmos os argumentos de Eugênio Bucci como ponto de partida para pensarmos as relações entre história e ficção na televisão, por meio das minisséries históricas, duas questões sobressaem-se: 1) quais os limites da separação realizada pelo autor entre escrita da história profissional - historiografia - e a imaginação televisiva da história; e 2) como pensar a recepção destes produtos televisivos sobre a história pela "plateia".

Sobre o primeiro ponto, vimos que os autores e produtores destes produtos televisivos utilizam-se não somente a consultoria de historiadores e estudiosos da história profissionais para a construção das tramas como também se apropriam amplamente da historiografia como fonte de pesquisa para a elaboração dos produtos. Nas três minisséries objetos de pesquisa do projeto é perceptível a presença de argumentos, situações e interpretações, transformadas em produto audiovisual, tiradas de pesquisas empreendidas por historiadores. Esta constatação nos leva a 
questionar os limites do argumento de Bucci a respeito da separação entre narrativa historiográfica - que "passa na mão e na cabeça do historiador" - e narrativa televisiva sobre a história - pensada na esteira do "simples entretenimento" alienante. A pergunta fundamental que se coloca, neste sentido, é em que medida a historiografia perde seu sentido de potência reflexivo quando se torna fonte para a elaboração do produto televisivo sobre a história? Será que perde realmente? Quais questões transparecem no procedimento de transformar argumentos históricos escritos em sons e imagens?

A respeito da segunda questão colocada, podemos dizer que Bucci faz tábula rasa do conceito de plateia. Ele parte do pressuposto de que a história é transformada, na televisão, em mero passatempo para divertimento da audiência, ou seja, ele toma o telespectador como sujeito passivo no processo de atribuição de sentidos sobre o produto televisivo. O que nos interessa investigar, neste sentido, são os diferentes olhares que se lançam sobre as minisséries históricas, e sobre a história de modo geral, pelo público consumidor de televisão, considerando que este público é heterogêneo e que compartilha de outros espaços de formação histórica, como as aulas de história, livros de história, filmes etc. Investigar como ocorre a recepção das minisséries televisivas significa pensar a especificidade da contribuição que a televisão pode dar - e se ela pode mesmo dar - a respeito do entendimento que a população brasileira tem sobre a sua história.

É importante destacar que nem todos os autores que se debruçaram sobre as relações entre a história e suas possíveis narrativas televisivas ou fílmicas concordam com os argumentos apresentados por Eugênio Bucci. Dentre eles, Robert Rosenstone é aquele que mais incisivamente trabalha com a ideia de que o conhecimento histórico pode ser apresentado e adquirido por meio de narrativas que utilizam imagens e sons para interpretar e representar o passado.

Rosenstone observa que, muitas vezes, roteiristas, cineastas e produtores de filmes e produtos televisivos de temática histórica utilizam as mesmas técnicas de pesquisa que um historiador profissional para investigar, interpretar e apresentar o passado na forma de um relato. A diferença entre eles estaria, portanto, na linguagem utilizada para levar a mensagem ao receptor: enquanto os historiadores tradicionais utilizam o relato escrito, os produtores de filmes cinematográficos e televisivos utilizam 
as imagens e os sons. O autor, neste sentido, leva a termo a possibilidade, já aventada desde meados do século XX, de uma escritura fílmica da história. ${ }^{23}$

O autor, no entanto, argumenta que o que faz um filme, de ficção ou documentário, ser considerado histórico não é a mera apresentação de uma "realidade" - acontecimentos, fatos e personagens - passada, mas o tipo de reflexão que possibilita:

O cinema, em especial o filme dramático, faz exigências especiais do historiador tradicional, pois vai além da constituição dos fatos, ou seja, a criação dos fatos por meio da escolha de certos vestígios do passado (pessoas, acontecimentos, momentos) aos quais são dados destaques porque são considerados importantes e dignos de serem incluídos em uma narrativa. [...] acho que existem duas maneiras de encarar a invenção de personagens, diálogos e incidentes que constitui uma parte inevitável do filme histórico dramático e não totalmente estranha ao documentário. É possível encarar a contribuição de tais obras em termos não apenas dos detalhes específicos por elas apresentados, mas, sim, no sentido abrangente do passado que elas transmitem, as ricas imagens e metáforas visuais que elas nos fornecem para que pensemos historicamente. Também é possível encarar o filme histórico como parte de um campo separado de representação e discurso cujo objetivo não é fornecer verdades literais acerca do passado (como se a história escrita pudesse fazêlo), mas verdades metafóricas que funcionam, em grande medida, como uma espécie de comentário, e desafio, em relação ao discurso histórico tradicional (ROSENSTONE, 2015: p. 23-24).

A contribuição de Rosenstone para a compreensão das relações entre história e ficção na televisão revela-se importante na medida em que avança na discussão da especificidade da narrativa audiovisual em relação ao conhecimento histórico. Diferentemente de Eugênio Bucci, Rosenstone não vê no antagonismo entre constituição do real = História $\mathrm{x}$ invenção ficcional = Ficção o problema para pensar historicamente os filmes dramáticos históricos, ao contrário, o cinema, ao abordar a história, não poderia proceder de outra maneira senão inventar personagens, situações, contextos etc. A especificidade da contribuição dos filmes para a história, no sentido apresentado pelo autor, consiste na elaboração de metáforas visuais que possibilitem que o espectador ou pense historicamente ou comente e desafie o

${ }^{23}$ A referência aqui é, evidentemente, o famoso ensaio de Marc Ferro Existe uma escritura filmica da História?, onde o historiador francês trabalha com a hipótese de que o cinema pode oferecer uma contribuição específica à história na medida em que propõe uma narração que se converte em imagens. Ver: RAMOS, Alcides Freire. O Canibalismo dos Fracos: cinema e história do Brasil. Bauru: Edusc, 2002. 
discurso histórico tradicional. Em ambas as perspectivas, Rosenstone aponta para a necessidade de se investigar sobre os modos como quem assiste ao filme histórico produz reflexão sobre a história apresentada e sua relação com a contemporaneidade por meio das visualidades propostas, ficcionalmente, pelos produtos audiovisuais.

Em um país onde a televisão ocupa, cada vez mais, o lugar de veículo emissor de enunciados sobre a realidade (presente, passada ou futura), compreender as maneiras como as pessoas atribuem sentido à história através da mediação dos produtos audiovisuais é essencial para o futuro da História enquanto disciplina produtora de conhecimento sobre o mundo em que vivemos.

\section{Referências bibliográficas}

BUCCI, Eugênio. A história na era de sua reprodutibilidade técnica. In: BUCCI, Eugênio; KEHL, Maria Rita. Videologias: ensaios sobre televisão. São Paulo: Boitempo, 2004.

KEHL, Maria Rita. O espetáculo como meio de subjetivação. In: BUCCI, Eugênio; KEHL, Maria Rita. Videologias: ensaios sobre televisão. São Paulo: Boitempo, 2004.

RAMOS, Alcides Freire. O Canibalismo dos Fracos: cinema e história do Brasil. Bauru: Edusc, 2002.

ROSENSTONE, Robert. A história nos filmes, os filmes na história. Tradução de Marcello Lino. Rio de Janeiro: Paz e Terra, 2015.

SORLIN, Pierre. La Storia nei Film: interpretazione del passato. Firenze: La Nuova Italia, 1984.

WHITE, Hayden. Meta-História: a imaginação histórica do século XIX. São Paulo: EDUSP, 1992.

Enredo e verdade na escrita da história. In: MALERBA, Jurandir (org.). A História Escrita. Editora Contexto. 2006. 